\title{
The rule of admissibility of evidence in the criminal process of continental Europe ${ }^{1}$
}

\author{
A regra de admissibilidade da prova no \\ processo penal da Europa continental
}

\section{Jerzy Skorupka²}

Department of Criminal Procedure, University of Wroclaw, Poland

jerzy.skorupka@uwr.edu.pl

http://orcid.org/0000-0002-6123-5538

\begin{abstract}
This paper presents a doctrinal review of the rule of admissibility of evidence in the criminal process of continental Europe, which can be understood narrowly as applying exclusively to the question of acceptability, i.e. determination what evidence can be admitted. This rule can also be understood in broad terms and applied to determine not only the admissibility of evidence but also its relevance and adequacy. Much attention was paid to the functions performed by the admissibility rule, especially its guarantee function. The state of scientific discussion on the recognition of unlawfully obtained evidence as "inadmissible evidence", and the author's views on this issue were also presented.

KEYWORDS: criminal process; law of evidence; admissibility of evidence: legality of actions of authorities; postulate of the moral integrity of the justice system.
\end{abstract}

ResUMO: Este artigo apresenta uma revisão doutrinária sobre a regra da admissibilidade da prova no processo penal da Europa continental, que pode ser entendida estritamente como aplicável somente à questão da admissibilidade, ou seja, da determinação de qual prova pode ser admitida. Essa regra pode também ser entendida em termos amplos e aplicada para determinar não somente

1 This work is a result of the research project financed by the National Science Centre No. 2017/27/B/HS5/00854.

2 Professor, Director of the Department of Criminal Procedure, University of Wroclaw (Poland); Judge of the Appellate Court in Wroclaw (Poland). 
a admissibilidade da prova, mas também a sua relevância e pertinência. Muita atenção foi direcionada para as funções desempenhadas pelas regras de admissibilidade, especialmente a sua função de garantia. Também são expostos o estado da discussão científica no reconhecimento de provas obtidas ilicitamente e a posição do autor sobre a questão.

Palavras-chave: processo penal; direito probatório; admissibilidade da prova; legalidade dos atos estatais; postulado de integridade moral do sistema de justiça.

\section{INTRODUCTION}

The rule of admissibility of evidence is an important procedural concept. The rule expresses the norm that only evidence that is admissible by applicable law may be introduced into criminal proceedings. Provisions of the law of evidence which define admissible and inadmissible evidence should be understood in broad terms. The notion of "applicable law" consists of statutory provisions, usually expressed as codes of criminal procedure, the provisions of applicable constitutions, which generally contain clauses prohibiting the use of torture and cruel, inhuman or degrading treatment, as well as corporal punishment. The notion also extends to provisions of international law, including that of the European Union $^{3}$ and the Council of Europe ${ }^{4}$.

3 The law of the European Union is applied in national legal systems in accordance with the principles of primacy, direct effect and indirect effect of EU law. According to the principle of primacy (supremacy) of European Union law over domestic laws of EU Member States, in the situation of a conflict between a rule of national law of a given Member State and a rule of European Union law, priority must be given to the rule of EU law. In such a situation, the primacy principle prevents the application of the rule which forms part of the national legal system of the Member State concerned. The principle of primacy applies to all legally binding sources of European Union law: its primary and secondary legislation, as well as international agreements concluded by the European Union with third countries. The provisions of the European Union law falling within the scope of national laws of evidence include, in particular, framework decisions and directives of the Parliament and of the Council.

4 A key international instrument affecting national laws of evidence is the European Convention for the Protection of Human Rights and Fundamental Freedoms. 
The law of evidence specifies that only certain measures of evidence $^{5}$ are admissible, namely those including evidence given by persons, i.e. testimony given by the accused and witness and reports drafted by expert witnesses. National procedural laws do not define the measures of evidence obtained from what is known as "material sources of evidence". The notion and classification of material measures of evidence were formulated by the science of evidence, based on the analysis of evidentiary procedures permitted by law, in particular the examination of a person, location and objects or the procedural experiment. By permitting the examination of a location, person or object and the carrying out of a procedural experiment, the law permits the measures of evidence which are obtained in the course of those evidentiary procedures. The law of evidence does not explicitly define the material measures of evidence despite the fact that such measures of evidence are established by statutory provisions that govern evidentiary procedures. National procedural laws permit the use of material measures of evidence but do not define what a material measure of evidence is or specify the existing types of such measures. National law merely provides that material measures of evidence comprise any measures of evidence obtained from the examination of a location, person and objects, a procedural experiment and other evidentiary procedures specified by law. Consequently, it is entirely possible that a measure yet unknown (unnamed), which at some point will become accessible through examination in consequence of scientific and technological progress, may be classified as evidence in the future. In such a case, such evidence should be considered admissible under law ${ }^{6}$.

EUROPEAN CONVENTION OF HUMAN RIGHTS, adopted in Rome on $4^{\text {th }}$ November 1950. Available at: https://www.echr.coe.int/documents/convention_eng.pdf. (access: December 20, 2020). Hereinafter: the ECHR.

5 In an attempt to address the ambiguity of the notion of "evidence", in this paper I use that term to refer to both sources and measures of evidence; a source of evidence is a person or object from which the evidence originates, whereas a measure of evidence is the medium that contains information about the facts to be proved, e.g. testimony of the accused, a witness's testimony or a report of an expert witness, features and characteristics of an object; the notion of "evidence" understood strictly embodies a measure of evidence.

6 Throughout the history of the criminal process many measures of evidence have "appeared" thanks to the development of science, e.g. fingerprints, trace evidence, DNA traces. 
On the other hand, in most cases, the law of evidence clearly indicates what evidence is considered inadmissible. Such restrictions on the admissibility of evidence are expressed by "evidentiary prohibitions", i.e. norms prohibiting proof of specific facts (e.g. the course of the deliberations and voting on a verdict), proof of facts by means of specific types of evidence (e.g. testimony of a lawyer representing the accused) and the use of certain methods of obtaining evidence (e.g. torture or corporal punishment).

The rule of admissibility of evidence is an important guarantee. According to that rule, the facts relevant to the determination of the accused's guilt can only be established by means of legally admissible evidence. National legislators have developed procedural laws of evidence in a way that enables the carrying out of evidentiary activities (understood as the conduct of participants in evidentiary procedures) exclusively in a pre-determined manner. By doing so, national legislators legitimise the conduct of the participants in the process as evidentiary activities carried out as part of criminal proceedings. Thus, the method of conducting evidentiary proceedings, i.e. the collection, recording and taking of evidence, may not be discretionary but is strictly regulated. If evidence is acquired and used in an unlawful manner, law enforcement authorities gain an unfair advantage over the accused. Instead of resorting to dishonest, and hence unfair, conduct that is not legitimised by the law, law enforcement authorities should use the capabilities and resources that the state has already put at their disposal. As a guarantee, the rule of admissibility of evidence ensures that a citizen (the accused) knows how the evidentiary proceedings will be conducted. The awareness that factual findings in criminal proceedings will be determined based on evidence admissible under law provides the accused with the opportunity to predict what decisions may be taken by criminal justice bodies and effectively defend themselves against prosecution. On the other hand, if law enforcement authorities could determine the facts based on evidence that is inadmissible and thus contrary to the law of evidence, the defence of the accused's case would be difficult or even impossible.

Notably, the rule of admissibility of evidence is an important safeguard of the accused's legal interests. Indeed, it draws the boundaries of the accused's "protective sphere", which must remain free from any 
interference by criminal justice bodies. In such a way, the accused is protected against unlawful violations of their realm of permissible behaviour and freedom and economic activity which could otherwise result from the use of inadmissible evidence. The rule of admissibility of evidence also serves as a safeguard of public interest. After all, it defines the sphere of permitted procedural activities for state authorities, and thus sets the limits for acceptable interference with the rights and freedoms of participants in criminal proceedings.

Another guarantee provided by this rule concerns the prevention of the arbitrary conduct on the part of criminal justice bodies, which, in turn, ensures that the rights and freedoms of a citizen (the accused) are respected. Thanks to this guarantee, the accused is not at the mercy of law enforcement authorities, the public prosecutor or the court.

\section{THE IMPORTANCE OD THE RULE OD ADMISSIBILITY OF EVIDENCE}

The rule of admissibility of evidence is a legal construct deliberately designed and developed by national legislators to achieve specific procedural objectives and used to achieve these objectives. In consequence of the above, the offence, its perpetrator and the accused's guilt can only be established on the basis of facts established following the taking of legally admissible evidence.

The rule of admissibility of evidence is connected with the right of the parties to criminal proceedings to request that evidence be taken by a criminal justice body (the court during the trial and, in pre-trial proceedings, by the prosecutor or other competent authority). The taking of evidence is the activity that involves including in the criminal process measures of evidence originating from sources of evidence. This is done by means of evidentiary procedures, which may involve an interview of the accused or a witness, examination of a person, location or object, a search of a person or premises, etc. Although different entities may be entitled to request the taking of evidence, the initiative in evidence-taking may always be undertaken ex officio or at the request of an authorized entity, if a law so permits. The legal design of initiative in evidence-taking depends on the adopted model of the criminal process and the underlying model of evidentiary proceedings, which may be based on the inquisitorial 
or adversarial principle and on the principle of truth. Depending on the model, criminal justice bodies and parties to the proceedings have a different impact on evidentiary proceedings. In a model which is based (entirely or predominantly) on the inquisitorial principle, the scope of evidentiary proceedings, and thus the determination of facts, will be significantly influenced by criminal justice bodies (the police, prosecutor, court). In a model based (entirely or predominantly) on the adversarial principle, evidentiary proceedings at the main trial are conducted by the parties (the prosecution and the accused), while the court's authority to take evidence ex officio is limited.

In contemporary criminal processes of continental Europe, evidence may be taken if the following conditions are met: (1) the evidence must be admissible, (2) the fact to be proven must be relevant to the resolution of the case; (3) the evidence must be relevant to establish factuality of a given circumstance; (4) it is possible to take the evidence. Sometimes, a further condition is added, namely that the taking of evidence must not be intended to protract the proceedings.

The rule of admissibility of evidence can therefore be understood narrowly as applying exclusively to the question of acceptability, i.e. determination what evidence can be admitted. This rule can also be understood in broad terms and applied to determine not only the admissibility of evidence but also its relevance and adequacy.

The rule of admissibility of evidence in the criminal process of continental Europe is determined by three elements:

a) the principle of truth, which expresses the requirement that the findings of facts must reflect the reality,

b) the principle of expediency, which requires that proceedings be conducted swiftly and that the case be resolved within a reasonable time,

c) the rights and freedoms of the accused and of the persons giving evidence, which lay down boundaries that must be respected by criminal justice bodies collecting evidence and introducing it into the criminal process.

The right to initiate evidentiary procedures was introduced in the 19th-century criminal codifications and was associated with the recognition of the accused as a subject rather than an object of the criminal 
process. However, the principles governing the introduction of evidence in the criminal process, including the rule of admissibility of evidence, were only defined in 20th-century criminal codifications. This does not mean that there were no earlier rules on the admissibility of evidence in the criminal process. Changes of measures of evidence and principles governing the introduction of evidence accompanied the development of the criminal process. However, the rules of the criminal process of continental Europe have repeatedly established subjective and objective limitations concerning the proving of facts relevant to the resolution of the case. For a long time, the law provided that certain categories of persons have no capacity to be witnesses in criminal proceedings. The evidence obtained from such persons was inadmissible. The law also defined measures that could not constitute evidence. It was inadmissible to prove facts through such measures.

\section{THE DEVELOPMENT OF THE RULES ON ADMISSIBILITY OF EVIDENCE - HISTORICAL APPROACH}

\subsection{Ancient Greece}

In ancient Greece, ${ }^{7}$ Aristotle divided the means available to a speaker in court into pisteis entechnoi, i.e. means dependent on the art of rhetoric, and pisteis atechnoi, i.e. means independent of rhetorical proficiency (Retoryka (The Rhetoric) 1355 b 35). In order to be considered as belonging to the art of rhetoric, means of persuasion needed to originate from that art. According to Aristotle, witnesses' testimonies, evidence given under torture and written statements did not belong to the art (of rhetoric) ${ }^{8}$.

7 See: BONNER, Robert J. Evidence in Athenian Court. Chicago 1905; LIPSIUS, Justus Herman. Das attische Recht und Rechtsverfahren. Leipzig 1905-1915. p. 866-900; HARRISON, Alick Robin Walsham, The Law of Athens. Procedure. Oxford 1971, p. 133-154; MACDOWELL, Douglas M. The Law in Classical Athens. London, 1978. p. 242-247.

8 See: ARYSTOTELES. Retoryka. In: ARYSTOTELES. Dzieła wszystkie, v. 6. Warszawa 2001. 
An exhaustive list of pisteis atechnoi, provided by the Stagirite elsewhere in The Rhetoric (1375 a $24 \mathrm{f}$ ), includes laws, witnesses testimonies, evidence given under torture, contracts, oaths. It was a common principle to listen to both parties to the dispute and to give the accused a chance to justify themselves. The Athenian oath sworn by judges included the promise to hear the accuser, the accused and the latter's counsel ${ }^{9}$. It appears that the oath was not necessary where the case was self-evident ${ }^{10}$. Therefore, statements of the accused given during the trial should be added to the list of pisteis atechnoi.

In the legal process of ancient Greece, parties to a dispute were obliged to present the law (nomos, nomoi) or resolutions of the popular assembly (psephisma, psephismata) on which they relied. The parties had to find and rewrite such instruments on their own. Persons invoking a non-existing law faced the death penalty ${ }^{11}$. Wills, contracts, books of accounts were among documents constituting procedural evidence. Testimonies of witnesses (martyria, martyriai) were the crucial proof during a trial. ${ }^{12}$ In Athens, only free adult males had the privilege of testifying. As stated by most commentators, female Athenian citizens could not give evidence during the trial. ${ }^{13}$ The testimony of slaves could constitute evidence only if extracted by torture. It was then considered more credible than the testimony of a free man (martyriai).

Similarly, persons who had lost their Athenian citizenship could not serve as witnesses ${ }^{14}$. Still, foreigners ${ }^{15}$ could give testimony in public ${ }^{16}$ and private ${ }^{17}$ cases. Parties to a dispute could not be witnesses in their

9 See: DEMOSTENES. Przeciw Timokratesowi. p. 149-151.

10 See: ARYSTOFANES. Osy. p. 919.

11 See: DEMOSTENES. XXVI 24.

${ }_{12}$ For a more detailed discussion, see: LEISI, Ernst. Der Zeuge im attischen Recht. Frauenfeld 1907; MIRHADY, David C. Athens' Democratic Witness. Phoenix, 56/3, p. 255-274, 2002.

13 See: GAGARIN, Michael. Women in Athebian Court. Dike 1, p. 43, 1998.

14 See: DEMOSTENES. XXI 95.

15 See: HARRISON, Alick Robin Walsham, The Law..., p. 138.

16 See: DEMOSTENES. XXXV 14; HYPEREJDES. V 33.

17 See: DEMOSTENES. XIX 146; AJSCHINES. II 155. 
own case ${ }^{18}$. However, testimony in support of a litigant's case could be given by persons who spoke on their behalf (synegoroi). ${ }^{19}$ Relatives of a party to the proceedings were allowed to testify. It is assumed that Athenian law prevented jurors hearing a given case from acting in the capacity of witnesses ${ }^{20}$.

\subsection{Ancient Rome}

In Roman law, there were no statutory rules for dealing with evidence. The Roman theory of evidence was not developed to a degree sufficient to fully restate the principles of evidentiary proceedings. The majority of sources concerning evidence in criminal trials of the Republican era appear in court speeches, which are devoid of theoretical references. Roman law provided for no list of admissible measures of evidence. A piece of evidence, proof (probatio), understood as a measure of evidence was defined as the information about circumstances relevant to the adjudication of a dispute. It was the parties who were required to present and take evidence. Neither the judge presiding over the trial (quaesitor) nor the multi-person tribunal had any participation in the taking of evidence. The burden of proof (onus probandi) rested on whoever made the claim.

Roman law did not introduce a list of admissible measures of evidence. Consequently, there were no restrictions on the admissibility of evidence. The only known categorisation of evidence, the one cited by Quintilian ${ }^{21}$ and derived from Aristotle, was based on the distinction

18 See: DEMOSTENES, VII 46.

19 See e.g.: ISAJOS, XII 4; AJSCHINES, II 170.

20 See: HARRISON, Alick Robin Walsham, The Law..., p. 138.

21 Quintilian, or Marcus Fabius Quintilianus, c. 35- c. 96 AD, Roman rhetorician and rhetoric educator, advocate. The author of The Institutes of Oratory; or, Education of an Orator. In Twelve Books (Latin: Institutionis oratoriae libri $X I I)$, which presents the theory of rhetoric, remarks about foundational education and a depiction of the ideal teacher. In Book V of the Institutio Oratoria, Quintilian presents the types of evidence in the Roman legal process, including evidence derived from the court proceedings themselves, public opinion and rumours, evidence extracted by torture, testimonies of official documents, oaths, witness testimonies, evidence derived from laws, circumstantial evidence. 
between artificial proofs (probationes artificiales) and natural proofs (probationes inartificiales) ${ }^{22}$. According to Quintilian, artificial proofs originate from the speaker himself, i.e. the prosecutor and the advocate, are a product of their rhetorical skills. The above category was said to include arguments, which in practice denoted circumstantial evidence ${ }^{23}$. Natural proofs consisted of evidence obtained from sources external to the speaker, which included „appropriate” measures of evidence, namely those intended to demonstrate the existence or non-existence of certain past events. Probationes inartificiales included witness statements, documents, etc.

The key evidence was the testimony of witnesses (testimonia). A special type of witness was the laudator (praiser), i.e. a character witness called during the trial to give verbal or written testimony in support of the accused's case, his conduct and lifestyle. The laudator's testimony constituted a measure of evidence. Another type of witness was the index (informant), an accomplice who confessed to the crime. An index received immunity or even a reward. An index was questioned at the preparatory stage of the proceedings and then as a witness during the trial. Expert witnesses were not considered a separate source of evidence; they were treated as witnesses, albeit of a special kind.

As a rule, only freemen could be witnesses, although this condition was not formally defined until the 5th century $\mathrm{AD}^{24}$. The criminal process of the Republican era did not provide for any common, statutory restrictions on the admissibility of testimony on the grounds of sex, societal status or age of a witness, their foreign origins or even

${ }^{22}$ In Book V of the Institutio Oratoria 5.1.1. (Liber Quintus) Quintus writes: "Ac prima quidem illa partitio ab Aristotele tradita consensum fere omnium meruit, alias esse probationes quas extra dicendi rationem acciperet orator, alias quas ex causa traheret ipse et quodam modo gigneret; ideoque illas atechnous, id est inartificiales, has entechnous id est artificiales, vocaverunt" (To begin with it may be noted that the division laid down by Aristotle has met with almost universal approval. It is to the effect that there are some proofs adopted by the orator which lie outside the art of speaking, and others which he himself deduces or, if I may use the term, begets out of his case. The former therefore have been styled inartificial proofs, the latter or artificial.).

See: LITEWSKI Wiesław. Rzymski proces karny. Kraków 2003, p. 93.

${ }^{24}$ C. $4,20,10$. 
indecency or previous convictions. Some scholars present the view that children were customarily excluded from testifying in cases against their parents ${ }^{25}$, but others argue that such a relationship was merely a ground for a refusal of testimony, known already in the times of the Republic. Paulus's testimony that a son is not a suitable witness in his father's case, and the father - in the son's case ${ }^{26}$ (or, more broadly, in a case concerning the daughter, grandson or grandfather), ${ }^{27}$ is sometimes interpreted as referring to testimony given in support rather than to the detriment of, a party to the dispute ${ }^{28}$.

The first formal subjective restrictions on the admissibility of testimony were introduced by Emperor Augustus, ${ }^{29}$ who resolved that in cases involving the charge of vis, no testimony for the accuser's case may be given by slaves freed by the defendant (or the defendant's father), minors, persons convicted of a public offence and not reinstated to their previous status, offenders held in shackles or in prison, persons fighting wild animals (bestiarii), female prostitutes, as well as all persons convicted, or even accused, of accepting a financial advantage for giving or refraining from giving testimony.

According to Ulpian (as quoted in the Collatio) ${ }^{30}$, the list of persons strictly excluded from testimony also comprised of freedwomen of the accused, the accused's ascendants or freed slaves (of both sexes) of any of the accused, or the accused's ascendants, any slaves freed by the above freedmen (or freedwomen), men who hired themselves as gladiators or bestiarii (with the exception of javelin throwers), as well as persons who have appeared or were to appear in public.

It was also pointed out that the prosecution should not appoint as a witness a person previously accused in a public trial or a person who

25 See: ZUMPT, August Wilhelm. Das Criminalrecht der Römischen Republik. Berlin 1869, p. 256 and 267-268.

26

27

28 processo criminale di età classica. In: Studi in onore di Arnaldo Biscardi. v. 3. Milano 1982, p. 234.

29

30

Rev. Bras. de Direito Processual Penal, Porto Alegre, v. 7, n. 1, p. 93-122, jan.-abr. 2021. 
was under the age of $20^{31}$, (although the Lex Iulia de vi refers to the age of maturity) ${ }^{32}$. In addition, no person who has already testified against the accused could be appointed as a witness for the accused ${ }^{33}$. Persons suspected of bias, in particular, those "brought by the accuser from their own home" ${ }^{34}$, as well as those who have fallen into infamy as a result of their lifestyle ${ }^{35}$ were also disqualified as witnesses.

Moreover, judges hearing the case, advocates ${ }^{36}$ and jurors were generally disqualified as witnesses. There was also a rule prohibiting a party from acting as a witness in their case. ${ }^{37}$

During the Republican period, the accused's statements, including their admission of guilt (confessio), did not constitute evidence. The accused's admission of guilt resulted in the proceedings ending immediately with conviction. However, Seneca, who lived in the 1st century AD, expressed the principle that both parties to a dispute should be heard: "Quicunque aliquid statuerit, parte inaudita altera, Aequum licet statuerit, haud aequus fuerit" 38 .

During the Imperial period, the confessio obtained the status of evidence. As such, the admission of guilt was required to be examined in the light of other evidence gathered, subject to the proviso that if the prosecution's allegations are not supported by other evidence, the accused's admission of guilt should not be treated as evidence of a crime the accused has allegedly committed ${ }^{39}$.

31 D. 22, 5, 20. Cf. GIUFFRE, Vincenzo. La repressione criminale nell 'esperienza romana, Napoli 1997, p. 152.

32 D. 22, 5, 3, 5 and Coll. 9, 2, 2.

33 D. 22, 5, 23. A different rule is expressed in C. 4, 20, 13.

34 D. 22, 5, 24; Coll. 9, 3.

35 Collatio 9, 3.

36 D. 22, 5, 25. See also ZUMPT August Wilhelm. Das Criminalrecht..., p. 271-272.

37 D. $22,5,10$.

38 "Whoever shall have determined anything without hearing the other side, may have decreed justly, yet he will not have been just." SENECA, Medea, Poznań 2000, p. 199-200.

39 D. $48,18,1,17$; D. $48,18,1,27$. 
During the reign of Emperor Constantine, the spontaneous confessio was treated as a sufficient basis for conviction in cases of capital offences, namely adultery, manslaughter or witchcraft. A conviction could be handed down also in the absence of the perpetrator's confession, if there were consistent statements of persons subjected to torture or made by witnesses ${ }^{40}$. It was permissible to torture the accused in order to obtain their confessio.

Public opinion views (rumores) had a major influence on the content of criminal judgments ${ }^{41}$. Such views constituted one of the measures of evidence.

\subsection{MedieVAl CRIMINAL PRocess AND RULES OF ADMISSIBILITY OF EVIDENCE}

In the early medieval process, no separate procedures were established for private and criminal cases, because both were based on a sense of harm suffered by a party, regardless of the nature of the harmful deed. In this context, all proceedings had features of a criminal trial.

Evidentiary proceedings were conducted not before but after the judgment was delivered. The proceedings took place out of court but in the presence of the opposing party. The person obliged to take evidence (usually the respondent/accused) thus had to solemnly swear to the opposing party (the claimant) that they would take evidence. Accordingly, the claimant/accuser had to acknowledge the result of the evidence-taking process. Anyone who failed to comply with the obligation to take evidence was outlawed. All types of evidence were regulated in a strictly formalistic fashion. These included the confession of guilt, the apprehension of the perpetrator in the act, oaths, the ordeals and witness testimony.

40 C. $9,47,16$.

41 In Book V of the Institutio Oratoria (5.1.2, Liber Quintus) Quintilian writes: "Ex illo priore genere sunt praeiudicia, rumores, tormenta, tabulae, ius iurandum, testes, in quibus pars maxima contentionum forensium consistit. Sed ut ipsa per se carent arte, ita summis eloquentiae viribus et adlevanda sunt plerumque et refellenda. Quare mihi videntur magnopere damnandi qui totum hoc genus a praeceptis removerant." 
The tribal period is considered the period of the emergence of ordeals (iudicia Dei), which were based on the belief that a deity would identify the guilty party. Recourse to this measure prevented other evidence from being used, as the ordeal was considered definitive proof. These included the trial by hot water (iudicium aquae ferventis) and the trial by hot iron (iudicium ferri candentis) and trial by cold water (iudicium aquae frigidae).

Under Germanic law, every free man could be a witness. However, a witness was required to possess property, at least movable, probably because of the necessity of paying a fine for perjury. A tenant sitting on someone else's land could not serve as a witness, even though he was granted the right to act as an oath-helper. A witness was also required to be settled in the county where the case was adjudicated. Perjurers, offenders sentenced to death and later pardoned, minors, women and persons deprived of honour did not have the capacity to serve as witnesses. The category of persons deprived of honour included comedians, jesters, men cohabitating with a concubine, sons of unmarried mothers and prostitutes.

The Swabian Mirror allowed the use of torture if there was circumstantial evidence (Indizien) that an accused person may have committed an offence, based on the credible testimony of one or two witnesses. After receiving such testimony, the court had one month to obtain the accused's confession to the commission of the alleged offence by means of torture. Over time, courts have been using torture in an increasingly arbitrary fashion, merely based on a suspicion of commission of a crime.

\subsection{Rules of evidence of the Constitutio Criminalis Carolina}

Adoption by the Reichstag (on 27 June 1532) of the Constitutio Criminalis Carolina (the Carolina, or "CCC"), has brought a new, strong impetus for the development of the theory of evidence, connected with the inquisitive type of criminal proceedings popularised by this codification. The system of formal proof envisaged in the Carolina has replaced the existing system of evidence in the accusatory process. The legal (formal) theory of evidence laid down in the Carolina determined the hierarchy and worth of individual types of evidence and set the requirements for 
valuable evidence. The accused ceased to be a subject of the proceedings and became the object of the proceedings.

According to the Carolina, not only witness statements and documents but also circumstantial evidence, suspicions and conjectures could be accepted as evidence. If the accused could not prove his innocence and did not confess, the judge ordered them to be tortured. The tortureinduced testimony given by the accused needed to be confirmed by testimony given after the torture. Only the admission of guilt obtained under the procedure provided for by Carolina was considered "complete" evidence and sufficient grounds for a conviction (art. 60 CCC).

The Carolina required that a witness should have a good reputation and therefore prohibited convicted perjurers from serving as witnesses. Furthermore, the codification did not allow unknown and hired witnesses.

The legal theory of evidence that governed the inquisitorial criminal process applied to all evidence used in the process. On the one hand, it has curtailed then-existing judicial arbitrariness related to the examination of evidence. On the other hand, the legal theory of evidence determined, in a rigid and top-down manner, what evidence the judge had to believe and what they had to refuse to believe and established what conclusions and legal consequences the judge had to draw from the evidence presented, regardless of their personal judgement.

The principles provided for in the inquisitorial criminal process did not apply to witchcraft trials, as such proceedings were considered to be taken against Satan himself, while the accused witch was perceived merely as Satan's victim and supine tool. No rules of the legal theory of evidence were followed in witchcraft trials. Even the testimony of children had full evidentiary value. No restrictions concerning the use of torture existed in such proceedings and presumptions could be admitted as evidence. Witchcraft trials saw the re-emergence of ordeals, which had been out of use since the Middle Ages, such as the trial of water.

\subsection{THE ADMISSIBILITY OF EVIDENCE IN THE MODERN ERA CRIMINAL PROCEEDINGS}

During the Enlightenment period, all stages of the French judicial process, including sentencing, were closed to the public, as it was the case in most European countries. The knowledge of the collected evidence 
was a privilege of the accuser. Under the Criminal Ordinance of 1670, the accused did not have access to evidentiary proceedings, did not know accusers, witnesses or the content of their testimonies, could not invoke any defences until the trial was completed, and was deprived of the right to legal representation. The magistrate, on the other hand, could admit any evidence submitted by the prosecution, even anonymous proof. The judge independently established the facts, notifying the accused. The judge questioned the accused once, before making the judgment. The accused was still treated as an object rather than a subject of the criminal process.

The rule that criminal proceedings should be conducted in camera and in writing was a consequence of the principle that the determination of the truth was the sole prerogative of the sovereign and the judges appointed by the sovereign. After all, the supreme authority, including the right to impose criminal penalties, could not be left in the hands of commoners. Another byproduct of procedural secrecy was a strict system of formal evidence. The essence and procedural value of evidence were defined by a long-standing tradition dating back to medieval times. As late as in the 18th century, proofs were classified as real, direct and formal; indirect, circumstantial and presumptive; and also as evident, considerable and non-considerable. ${ }^{42}$ In principle, the formal restrictions placed on evidence-taking were a means of the internal regulation of the absolute power that applied the law for its exclusive use.

Torture was a legitimate method of evidence-taking. As such, torture, independently from the "modern" inquisitive methods, was a living relic of the ancient probative methods such as ordeals, judicial duels or other "God's judgments". According to the procedure, if the accused endured torture and did not confess, the accuser was obliged to drop the charges. A consequence of the above rule was the custom, prevailing in cases of most serious offences, of ordering torture, but "subject to evidence". In such a case, upon the conclusion of torture, the judge was still allowed to adjudicate based on presumptions to prevent the accused's acquittal. This procedure offered the accused the "advantage" of being protected against capital punishment.

${ }^{42}$ See: JOUSSE, Daniel. Traite de la justice criminelle. Paris: Debure 1771, p. 660. 
The Austrian Franciscana, or the Book of Laws on Felonies and Grave Police Offences, enacted on 3 September 1803, emphasised the principle of "legal belief", expressed in the admissible finding of the accused's guilt based on certain rules of evidence despite the absence of the accused's confession. The new codification did not abolish the theory of legal evidence in Austrian criminal procedure, but the accused's admission of guilt was no longer the conclusive evidence.

Furthermore, under the Prussian Criminal Ordinance (Preussische Criminalordnung) of 1805, the obsolete "positive" form of the theory of legal evidence continued to govern the assessment of evidence. Accordingly, proofs were divided into complete, incomplete and less than incomplete (i.e. doubtful).

\subsection{The admissibility in France in the Napoleon Bonaparte era}

The Code of Criminal Procedure (Code d 'instruction criminelle) adopted in France on 16 December 1808 marked the beginning of a new era in the history of the European criminal process. Under the 1808 Code, anyone who had knowledge of a crime or its circumstances could serve as a witness. The hearing of witnesses by the judge during the investigation took place in camera and in the absence of the accused (art. 73). Before starting to testify, witnesses took an oath that they would tell the truth and only the truth. Pursuant to art. 322 of the Code, the following persons could not testify as witnesses: (1) father, mother, grandfather, grandmother and ascendants of the accused or a co-accused; (2) sons, daughters, grandchildren or ascendants of any of them; (3) brothers and sisters; (4) persons related by affinity in the first or second degree; (5) husband and wife, also divorced; 6) denunciators (whistleblowers, informants) paid for their services; unpaid denunciators could appear before the court as witnesses, but the court had to instruct the jury of their status (art. 323). Testimony given by the aforementioned persons was nevertheless valid provided that the prosecutor, the aggrieved person and the accused made no objection.

Napoleon Bonaparte introduced restrictions on certain persons' capacity to become a witness. In art. 510 of the Code, he stipulated that "the Princes and Princesses of Imperial Blood, the Grand Dignitaries 
of the State, and the Grand Judge the Minister of Justice shall not be summoned to appear as witnesses, even at a trial before the assembly of juries, unless the Emperor, at the request of a party and after obtaining the report of the Grand Judge, by special decree, gives His approval for their appearance".

\section{THE CONTEMPORARY DISCUSSION OF THE RULES ON ADMISSIBILITY OF EVIDENCE IN CRIMINAL PROCESS}

The concept of "admissible evidence" is currently under discussion in the European science of evidence and case law. The core of this discussion is the question of whether evidence obtained illegally can be deemed admissible. In fact, illegality in obtaining evidence should trigger relevant procedural sanctions including declaring it null and void or ineffective.

It is noted in the debate that the state is obliged to ensure the safety of its citizens. The state should introduce effective measures aimed at preventing and combating crime. The obligation to ensure the safety of citizens means that the state can, or even - if the circumstances of a given case so require - has to, resort to obtaining evidence in an unlawful manner. Since the 11 September 2001 attacks, the notion of admitting illegally obtained evidence has been expressed more often. The opinion is expressed that in extreme situations it is necessary to obtain testimonies by violence, especially in "ticking-bomb" scenarios. There are even more far-reaching proposals to legalise and institutionalise the use of torture. However, supporters of this view note that such drastic measures are exceptional and allowed only in extreme situations and that torture is only to be applied under supervision and must be governed by legally defined procedures ${ }^{43}$. In Germany, the discussion revolved around the use of physical and psychological violence by police officer Wolfgang

43 See: SLATER. Jerome. Tragic Choices in the War on Terrorism: Should We Try to Regulate and Control Torture? Political Science Quarterly, v. 121, no. 2, p. 191-215, 2006. DERSHOWITZ, Alan M. Is There a Torturous Road to Justice?, Los Angeles Times, 8.11.2001; DERSHOWITZ, Alan M. Why terrorism works: Understanding the threat, responding to the challenge. Yale University Press, 2002, p. 131-164. 
Daschner in connection with the abduction of the son of a well-known financier by Magnus Gäfgen ${ }^{44}$. In a "ticking bomb" scenario, violence is used against the accused in order to save or protect the life and health of other people. Opponents of violent evidence-taking measures counter the above rationale for extorting evidence by pointing to the ultimate value, namely the inherent dignity of a human being.

The necessity for the state authorities to maintain lawful forms of action is quoted in opposition to the views justifying the admission of unlawfully obtained evidence. After all, the authorities are obliged to act on the basis and within the boundaries of the law. The principle of legality governing the actions of authorities, as expressed in most European constitutions, prescribes the respect for and compliance with legal forms and methods of obtaining evidence in the criminal process.

The ECtHR expressed the view that the use of evidence obtained directly as a result of torture always makes the criminal process unreliable. In the judgment of the Grand Chamber in the case Jalloh v. Germany the Court stated that: “... incriminating evidence - whether in the form of a confession or real evidence - obtained as a result of acts of violence or brutality or other forms of treatment which can be characterised as tortureshould never be relied on as proof of [the victim's] guilt, irrespective of its probative value. Any other conclusion would only serve to legitimate indirectly the sort of morally reprehensible conduct which the authors of Article 3 of the [European Convention for the Protection of Human Rights and Fundamental Freedoms] sought to proscribe or, as it was so well put in the United States Supreme Court's judgment in the Rochin case, [...] to "afford brutality the cloak of law"45.

${ }^{44}$ See: EUROPEAN COURT OF HUMAN RIGHTS. Judgment of 1 June 2010, Gäfgen v Germany, no. 22978/05. https://hudoc.echr.coe.int/.

45 See: EUROPEAN COURT OF HUMAN RIGHTS. Judgment of 11 July 2006, Jalloh v Germany, no. 54810/00, §105. The same view was expressed in: EUROPEAN COURT OF HUMAN RIGHTS. Judgment of 21 September, Söylemez v Turkey, no. 46661/99, § 122; see also: GRAFFIN, Niel. The Legal consequences of Ill-treating Detainees held for Police Questioning in Breach of Article 3 ECHR. European Journal of Current Legal Issues, v. 20, no. 2, p. 5-6, 2014, http://webjcli.org/article/view/339/437. 
The said opinion has been repeated in other judgments. ${ }^{46}$ In $E l$ Haski v. Belgium, the ECtHR reiterated that the use of evidence obtained by torture and by inhuman or degrading treatment in criminal proceedings automatically renders the trial, as a whole, unreliable. The same standard should be applied to material evidence obtained directly through the use of torture ${ }^{47}$. It is irrelevant here whether the evidence obtained as a result of torture or inhuman treatment played a significant role in the making of a factual finding. The very fact of admitting such evidence to the criminal process is a factor determining the unreliability of the entire proceedings $\mathrm{s}^{48}$. Evidentiary prohibitions set out in Article 3 of the Convention are absolute in nature and have cross-border implications. Hence, it is unacceptable to use evidence (testimonies of witnesses' or the accused) obtained through international legal assistance from a person interviewed in another country with the use of torture or inhuman treatment.

According to the ECtHR, narrowly understood evidentiary prohibitions also apply to the evidence obtained as a result of a faulty fictitious transaction, which constitutes incitement of the accused to commit a prohibited act. The ECtHR has expressed such a position in Ramanauskas v. Lithuania. The Court held that "where an accused asserts that he was incited to commit an offence, the criminal courts must carry out a careful examination of the material in the file, since for the trial to be fair within the meaning of Article $6 \S 1$ of the Convention, all evidence obtained as a result of police incitement must be excluded. This is especially true where the police operation took place without a sufficient legal framework or adequate safeguards." ${ }^{49}$ The Court also found that where a national court establishes that the accused was incited to commit a prohibited act imputed to them, the Court will be obliged to exclude evidence obtained as a result of police provocation that was improperly carried out. In other

46 Cf. EUROPEAN COURT OF HUMAN RIGHTS. Judgment of 1 June 2010, Gäfgen v Germany, no. 22978/05, §§ 166-167.

47 See: EUROPEAN COURT OF HUMAN RIGHTS. Judgment of 25 September 2012, El Haski v Belgium, no. 649/08, § 85.

48 See: EUROPEAN COURT OF HUMAN RIGHTS. Judgment of 11 February 2014, Cěsnieks v Latvia, no. 9278/06, § 62-70.

49 See: EUROPEAN COURT OF HUMAN RIGHTS. Judgment of 5 February 2008, Ramanauskas v Lithuania, no. 74420/01, § 60. 
judgments, the ECtHR pointed to the obligation to exclude such evidence from the criminal process or apply a "procedure with similar consequences"

\section{THE AXIOLOGICAL FOUNDATIONS OF THE RULES ON ADMISSIBILITY OF EVIDENCE IN CRIMINAL PROCEEDINGS}

It is noted in the ongoing debate that if the principle of legality of the actions of authorities, the principle of respect for inherent human dignity, legal protection of individual freedoms and rights, including the right to privacy, and the prohibition of torture, inhuman and degrading treatment and the use of corporal punishment are introduced into national legal systems, then the authorities of the state should respect these principles. It is pointed out that the history of law provides numerous examples of the fact that a sovereign is obliged to respect the law that they have established. In the early Middle Ages (until 1100) there was a principle, expressed as a moral obligation, that the king rules within the law inherited from his ancestors and is obliged to respect that law. This obligation was reiterated in early medieval Christian writings. Saint Ambrose (c. 340-397), Bishop of Milan, claimed that kings were not subject to criminal law but nevertheless emphasized that the ruler should observe the laws he had established ${ }^{51}$.

In the late Middle Ages St. Thomas recommended that the ruler obeyed the law on account of his moral duty. In distinguishing between the "coercive" and "directive" force of the law, St. Thomas expressed the view that "when it comes to the directive force of the law, the ruler

50 See: EUROPEAN COURT OF HUMAN RIGHTS. Judgment of April 2014, Lagutin and Others v Russia, no. 6228/09, 19123/09, 19678/07, 52340/08 and 7451/09, § 117; Also: EUROPEAN COURT OF HUMAN RIGHTS. Judgment of 9 June 1998, Teixeira de Castro v Portugal, no. 44/1997/828/1034, §§ 34-36; EUROPEAN COURT OF HUMAN RIGHTS. Judgment of 26 October, Khudobin v Russia, no. 59696/00, § 135; EUROPEAN COURT OF HUMAN RIGHTS. Judgment of 15 December 2005, Vanyan v Russia, no. 53203/99, § 46-47; EUROPEAN COURT OF HUMAN RIGHTS. Judgment of 2 December 2014, Taraneks v Latvia, no. 3082/06, § 60.

51 See: AMBROSE OF MILANO. Epistulae, 21.9, where he wrote: "the emperor makes laws, so let him be an example of respect for that law"; see also: ISIDORE OF SEVILLE. Sententiae, 3.51. 
surrenders to the law of his own free will". As Thomas Aquinas said, that is why it had been stated in the Decrees of Gregory that "whoever obliges the other by the law that has been issued should himself respect that law. And the Sage teaches further: 'hold on to the law that you yourself have established"' ${ }^{52}$.

During the Renaissance, Jean Gerson ${ }^{53}$ indicated that the king may not kill anybody without applying the rules of due process of law (iuris ordine) and that the king may not take the life of anyone who has not been charged, brought to court and convicted. "The monarch and prelate, although they are usually said to be free from the binding force of the law (solutus legibus), should respect the law they have established to set an example to their subjects" ${ }^{54}$.

During the Enlightenment, Jean Bodin ${ }^{55}$, the greatest contemporary supporter of the absolute monarchy, claimed that the quintessence of sovereignty was that the sovereign should not be bound by any laws. Nevertheless, he believed that the kingdom should be governed, as far as possible (quantum fieri poterit), by laws rather than by the arbitrary will of the ruler. Beccaria, Montesquieu and Voltaire protested against the arbitrariness of governmental power. J. Locke also wrote about the need for the monarch to respect the law ${ }^{56}$. Notably, in the 18th century, the arbitrariness of the government that went beyond the law because of the alleged existence of royal prerogative was the reason for the action

52 See: TOMASZ Z AKWINU. Summa teologiczna. Prawo, I-II, q. 96.5., v. 13, p. 86, Londyn 1986.

53 Jean Gerson (1363-1429), Rector of the University of Paris, philosopher, reformer.

54 See: GERSON, Jean. Summa contra Ioannem Parisiensem (Opera, 1.11.152). In: KELLY, John M. Historia zachodniej teorii prawa. p. 199, Kraków 2006; KELLY, John M. A short history of western legal theory. Oxford University Press, 1992.

55 Jean Bodin (1530-1596), theoretician of the state, creator of the ideology of French absolutism, supporter of absolute monarchy. His ideas became the basis of absolute monarchy in France. His best-known work is The Six Books of the Republic. In the treaty entitled De la démonomanie des sorciers (Of the Demon-mania of the Sorcerers) Bodin recommended extremely brutal methods of punishing alleged witches.

56 See: LOCKE, John. Dwa traktaty o rządzie. London 1690, p. 310. 
taken in England against the Stuarts and the beheading of King Charles I and dethronement of King James II.

It is argued that the law is based on specific axiology. A set of axiological values is contained implicitly or explicitly in or outside the system of law to which it refers. The set of these values constitutes the moral basis of the law. Currently, in the European legal culture, human rights, including the right to a fair trial, are an important element of this set.

\section{Conclusions}

Bearing in mind the values expressed in the constitutions of the countries of continental Europe or in the preambles to these acts as well as those laid down in legal instruments of the European Union and the Council of Europe, which form part of national legal systems, one should say that justice, truth, freedom and inherent dignity of a human being constitute the axiological basis of the criminal process. They are the primary values of the criminal process. Recognising these values as fundamental values necessitate organising the criminal process in a way that would ensure that these values are respected and protected. Inherent human dignity must be protected fully and unconditionally. The remaining values, i.e. justice, truth and freedom are not absolute in nature and may be restricted according to the criteria laid down by the proportionality principle.

The fairness of the judicial (criminal) process refers to what is known as "procedural fairness". In accordance with the procedural fairness principle, the process is fair as long as it provides for guarantees of the parties to the proceedings. The essence of procedural fairness is the seeking of justice (a fair outcome) by means of properly designed procedural provisions that duly protect parties' rights. In the criminal process, procedural fairness requires that procedural provisions be developed in a way conducive to achieving a fair outcome in the most effective way possible. The implementation of the procedural fairness principle creates the presumption of a fair outcome on the object of the process (i.e. on the guilt of the accused). In such a case, it would be difficult to consider a court decision to be procedurally fair if the evidence of the accused's guilt had been obtained unlawfully. 
It should be added that the axiological basis of a legal system on which a legal order is based determines not only the direction of law-making but also the interpretation and application of laws. It is, therefore, the responsibility of the national authorities of continental Europe, including the criminal justices bodies, to construe the law in a pro-constitutional and pro-EU manner and apply the law in accordance with these values.

One should also recall the aforementioned requirement of foreseeability of court decisions. As a side note, one should remember that the period preceding the 19th century's legal codifications is considered to be the era of absent legal certainty. The reasons for this absence were the chaotic structure of legal authorities, particularism, the confusedness and ambiguity of customary laws, which led to arbitrary court decisions. It was hoped that the much-needed codification of law would result in developing a uniform body of law that would contain ready-to-use and accessible solutions. The law as a system was meant to be simple, coherent and complete ${ }^{57}$.

Nowadays, calls for legal certainty in the countries of continental Europe are made for reasons other than those quoted in the pre-codification period. Generally speaking, the causes of historical legal uncertainty have already been eliminated. It is now clear who makes the law and how it is made and the law itself is based on socially acceptable rules, principles and standards such as the right to a court or the right to a fair (honest) and impartial trial. However, this does not mean that the law is entirely certain. Whereas the pre-codification postulate of foreseeability of the law centred on abstractly expressed foreseeability, nowadays the foreseeability of the law, or rather of decisions to apply the law, is perceived in concrete terms. The parties have the right to assume that evidentiary proceedings in the criminal process will be carried out in accordance with legal principles and rules. They should expect that evidence-taking procedures will be performed in a way defined in the law and that only the legally admissible

57 See: CANALE, Damiano. The Many Faces of the Codification of Law in Modern Continental Europe. In: PATTARO, Enrico, CANALE Damiano, GROSSI, Paolo, HOFMANN, Hasso, RILEY, Patrick (Eds.). A History of the Philosophy of Law in the Civil Law World, 1600-1900. Series A Treatise of Legal Philosophy and General Jurisprudence. Netherlands: Springer 2009, p. 137. Online ISBN 978-90-481-2964-5. 
evidence will be taken. They should be able to anticipate that the rules of law will be interpreted holistically, in accordance with the principles of interpretation and according to the pro-constitutional and pro-EU interpretation and that similar cases will be decided in a similar manner. If, however, the criminal process involves steps taken without legal basis or in direct contravention of law, inadmissible evidence is collected and taken and the law is interpreted so as to justify illegal actions by authorities and violations of constitutional principles and values, the parties will have none ability whatsoever to predict the final outcome of their case.

One of the arguments raised in the ongoing debate concerns the requirement to preserve the moral integrity of the justice system. It is argued that the criminal process is a social tool and as such requires adequate legitimacy. Its existence is closely linked with the primary values of a given legal system. Thus, one should never allow for a discrepancy between the declared principles and actual actions of state bodies. The above assertion is crucial for the justice system since the authority to administer justice may only reasonably be invoked where the body enforcing compliance with the law itself respects the law. This means that the rules of the "procedural game" should be seen on an equal footing with the pursuit of the objectives of the criminal process defined in substantive law. ${ }^{58}$ Arguments referring to the postulate of the moral legitimacy of the justice system also refer to the notion that the rights and freedoms of an individual form a coherent system. A violation of these rights and freedoms results in a violation of the right to a fair trial. The effectiveness of human rights requires proper guarantees, i.e. the possibility of disqualifying illegally obtained evidence..$^{59}$ Accordingly, the question arises whether the judging of the accused's behaviour and determination of the accused's guilt (in other words, the administration of justice on behalf of the state) can be reconciled with permitting and accepting the use of fruits (benefits) of illegal activities of state bodies. ${ }^{60}$

58 See: ASHWORTH, Andrew. Exploring the integrity principle in evidence and procedure. In: MIRFIELD, Peter. SMITH, Roger. Essays for Colin Tapper. Oxford-New York 2003, p. 110.

59 Ibid. 115-116.

60 See: CHAU, Peter. Excluding Integrity? Revisiting Non-Consequentialist Justifications for Excluding Improperly Obtained Evidence in Criminal Trials. 
The postulate of the moral integrity of the justice system is procedural in its nature. It is linked to the (substantive) values that constitute the axiological basis of a given legal system. This postulate may not be fulfilled if there is a discrepancy between the declared principles and the actions taken as well as an inconsistency in a given system that manifests itself in the divergent behaviour of those acting within the system's framework. It is important insofar as invoking the requirement of the moral legitimacy of the justice system requires detachment from prevailing and changing social expectations. Nowadays, the people of continental Europe quite universally accept that the law may be infringed in connection with the prevention and combating of crime and, more generally, the protection of public safety. Societies approve actions taken by state bodies such as the use of prohibited methods of obtaining evidence. This is evidenced by, among other things, the views and arguments expressed in Germany in connection with the aforementioned case of Wolfgang Daschner ${ }^{61}$.

It is also pointed out that the argument concerning the moral integrity of the justice system should be reformulated into an argument based on the prohibition of profiting from illegal activity. The latter assumes that a key aspect of the disqualification of illegally obtained evidence is the assessment of whether such evidence, if admitted, would be procedurally beneficial to a party (basically, the prosecution) who requests the admission. If this is the case, the evidence should be disqualified. ${ }^{62}$ This approach deviates from the postulate of moral integrity of the justice system, although it is also based on the systemic assumption that one may not derive benefits from activities that are prohibited within a given system.

In conclusion, it is worth noting that the term "inadmissible evidence" should be understood broadly. Not only the evidence that is

In: HUNTER, Jill. ROBERTS, Paul. YOUNG, Simon. DIXON, David (Eds.) The Integrity of Criminal Process: From Theory into Practice. Oxford-Portland 2016, p. 275-277.

61 See: ESSLINGER, Detlef. Mildes Urteil im Folter-Prozess, Süddeutsche Zeitung, 21.12.2004. See also public opinion polls carried out in Germany by the Institut für Demoskopie Allensbach,Darf die Polizei Gewalt androhen, um Leben zu retten? Die große Mehrheit der Bevölkerung sagt: "Ja”, Allensbacher Berichte, v. 6, 2004.

CHAU, Peter. Excluding Integrity?... 
subject to a statutory prohibition of evidence-taking is inadmissible but also any evidence that has unlawfully been obtained. It is debatable whether such evidence should be disqualified based on any discrepancy with the applicable law or whether such disqualification should be reserved for infringements of certain, particularly significant norms expressing the fundamental values of a given legal system or infringements of a specific degree (severity). It seems that a position advocating strict observance of the law by state authorities should prevail. Any attempt to relativize this phenomenon will always lead to more opportunities for legal violations and illegal activities, in line with Gresham's Law that "bad money drives out good". Indeed, bad law will always drive out good law.

\section{References}

AJSCHINES. II 155.

AMBROSE OF MILANO. Epistulae, 21.9.

ARYSTOFANES. Osy. p. 919.

ARYSTOTELES. Retoryka. In: ARYSTOTELES. Dzieła wszystkie, v. 6. Warszawa 2001.

ASHWORTH, Andrew. Exploring the integrity principle in evidence and procedure. In: MIRFIELD, Peter. SMITH, Roger. Essays for Colin Tapper. Oxford-New York 2003.

BONNER, Robert J. Evidence in Athenian Court. Chicago 1905.

CANALE, Damiano. The Many Faces of the Codification of Law in Modern Continental Europe. In: PATTARO, Enrico, CANALE Damiano, GROSSI, Paolo, HOFMANN, Hasso, RILEY, Patrick (Eds.). A History of the Philosophy of Law in the Civil Law World, 1600-1900. Series A Treatise of Legal Philosophy and General Jurisprudence. Netherlands: Springer 2009.

CHAU, Peter. Excluding Integrity? Revisiting Non-Consequentialist Justifications for Excluding Improperly Obtained Evidence in Criminal Trials. In: HUNTER, Jill. ROBERTS, Paul. YOUNG, Simon. DIXON, David (Eds.) The Integrity of Criminal Process: From Theory into Practice. Oxford-Portland 2016.

DEMOSTENES. VII 46.

DEMOSTENES. Przeciw Timokratesowi. p. 149-151. 
DEMOSTENES. XIX 146.

DEMOSTENES. XXI 95.

DEMOSTENES. XXVI 24.

DEMOSTENES. XXXV 14.

DERSHOWITZ, Alan M. Is There a Torturous Road to Justice?, Los Angeles Times, 8.11.2001.

DERSHOWITZ, Alan M. Why terrorism works: Understanding the threat, responding to the challenge. Yale University Press, 2002.

ESSLINGER, Detlef. Mildes Urteil im Folter-Prozess, Süddeutsche Zeitung, 21.12.2004.

EUROPEAN CONVENTION OF HUMAN RIGHTS, adopted in Rome on $4^{\text {th }}$ November 1950. Available at: https://www.echr.coe.int/documents/convention_eng. pdf. (access: December 20, 2020).

EUROPEAN COURT OF HUMAN RIGHTS. Judgment of 1 June 2010, Gäfgen v Germany, no. 22978/05. https://hudoc.echr.coe.int/

EUROPEAN COURT OF HUMAN RIGHTS. Judgment of 11 February 2014, Cěsnieks v Latvia, no. 9278/06, https://hudoc.echr.coe.int/

EUROPEAN COURT OF HUMAN RIGHTS. Judgment of 11 July 2006, Jalloh v Germany, no. 54810/00, https://hudoc.echr.coe.int/

EUROPEAN COURT OF HUMAN RIGHTS. Judgment of 15 December 2005, Vanyan v Russia, no. 53203/99, https://hudoc.echr.coe.int/

EUROPEAN COURT OF HUMAN RIGHTS. Judgment of 2 December 2014, Taraneks v Latvia, no. 3082/06, https://hudoc.echr.coe.int/

EUROPEAN COURT OF HUMAN RIGHTS. Judgment of 21 September, Söylemez v Turkey, no. 46661/99, https://hudoc.echr.coe.int/

EUROPEAN COURT OF HUMAN RIGHTS. Judgment of 25 September 2012, El Haski v Belgium, no. 649/08, https://hudoc.echr.coe.int/

EUROPEAN COURT OF HUMAN RIGHTS. Judgment of 26 October, Khudobin v Russia, no. 59696/00, https://hudoc.echr.coe.int/

EUROPEAN COURT OF HUMAN RIGHTS. Judgment of 5 February 2008, Ramanauskas v Lithuania, no. 74420/01, https://hudoc.echr.coe.int/

EUROPEAN COURT OF HUMAN RIGHTS. Judgment of 9 June 1998, Teixeira de Castro v Portugal, no. 44/1997/828/1034, https://hudoc.echr.coe.int/ 
EUROPEAN COURT OF HUMAN RIGHTS. Judgment of April 2014, Lagutin and Others v Russia, no. 6228/09, 19123/09, 19678/07, 52340/08 and 7451/09, https://hudoc.echr.coe.int/

GAGARIN, Michael. Women in Athebian Court. Dike 1, p. 43, 1998.

GERSON, Jean. Summa contra Ioannem Parisiensem (Opera, 1.11.152). In: KELLY, John M. Historia zachodniej teorii prawa. Kraków 2006.

GIUFFRE, Vincenzo. La repressione criminale nell ,esperienza romana, Napoli 1997.

GRAFFIN, Niel. The Legal consequences of Ill-treating Detainees held for Police Questioning in Breach of Article 3 ECHR. European Journal of Current Legal Issues, v. 20, no. 2, 2014, http://webjcli.org/article/view/339/437.

HARRISON, Alick Robin Walsham, The Law of Athens. Procedure. Oxford 1971. HYPEREJDES. V 33.

ISAJOS, XII 4.

ISIDORE OF SEVILLE. Sententiae, 3.51.

JOUSSE, Daniel. Traite de la justice criminelle. Paris: Debure 1771.

KELLY, John M. A short history of western legal theory. Oxford University Press, 1992.

LEISI, Ernst. Der Zeuge im attischen Recht. Frauenfeld 1907.

LIPSIUS, Justus Herman. Das attische Recht und Rechtsverfahren. Leipzig 1905-1915.

LITEWSKI Wiesław. Rzymski proces karny. Kraków 2003, p. 93.

LOCKE, John. Dwa traktaty o rządzie. London 1690.

MACDOWELL, Douglas M. The Law in Classical Athens. London, 1978.

MANFREDINI, Arnoldo D. La testimonianza del liberto contro il patrono nel processo criminale di età classica. In: Studi in onore di Arnaldo Biscardi. v. 3. Milano 1982.

MIRHADY, David C. Athens' Democratic Witness. Phoenix, 56/3, 2002.

SENECA, Medea, Poznań 2000.

SLATER. Jerome. Tragic Choices in the War on Terrorism: Should We Try to Regulate and Control Torture? Political Science Quarterly, v. 121, no. 2, 2006.

TOMASZ Z AKWINU. Summa teologiczna. Prawo, I-II, q. 96.5, Londyn 1986. ZUMPT, August Wilhelm. Das Criminalrecht der Römischen Republik. Berlin 1869. 


\section{Additional information and author's declarations (scientific integrity)}

Acknowledgment: This work is a result of the research project financed by the National Science Centre No. 2017/27/B/HS5/00854.

Conflict of interest declaration: the author confirms that there are no conflicts of interest in conducting this research and writing this article.

Declaration of authorship: all and only researchers who comply the authorship requirements of this article are listed as authors; all coauthors are fully responsible for this work in its entirety.

Declaration of originality: the author assures that the text here published has not been previously published in any other resource and that future republication will only take place with the express indication of the reference of this original publication; he also attests that there is no third party plagiarism or self-plagiarism.

\section{Dados do processo editorial}

(http://www.ibraspp.com.br/revista/index.php/RBDPP/about/editorialPolicies)

- Recebido em: 22/02/2021

Equipe editorial envolvida

- Editor-chefe: 1 (VGV)

Autor convidado - invited author

- Editora-associada: 1 (KK)

\section{HOW TO CITE THIS ARTICLES (ABNT BRAZIL):}

SKORUPKA, Jerzy. The rule of admissibility of evidence in the criminal process of continental Europe. Revista Brasileira de Direito Processual

Penal, Porto Alegre, vol. 7, n. 1, p. 93-122, jan./abr. 2021.

https://doi.org/10.22197/rbdpp.v7i1.526

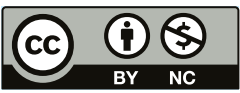

